\title{
The Dynamics of Social Capital in Influencing Use of Soil Management Options in the Chinyanja Triangle of Southern Africa
}

\author{
$\underline{\text { Jemimah M.Njuki }}^{1}, \underline{\text { Mariam T. Mapila }}^{2}$ Shamie Zingore $^{3}{ }^{3}$, and $\underline{\text { Robert Delve }}^{3}$
}

\begin{abstract}
Social capital has become a critical issue in agricultural development as it plays an important role in collective action, such as, management of common resources and collective marketing. Whilst literature exists on the role of social capital in the use and adoption of improved agricultural technology, such literature is fraught with issues of the measurement of social capital beyond membership of farmers in groups. We hypothesized that different types of social capital influence the adoption of soil management options differently. This study looked at the measurement of social capital, differentiating between the main types of social capital and employed factor analysis to aggregate indicators of social capital into bonding, bridging, and linking social capital. Using logit analysis, the role of these types of capitals on influencing use of different soil management options was analyzed. The study found that bonding, bridging, and linking social capital all influence the adoption and use of different soil management options differently, a trend that might be similar for other agricultural technologies as well. The study recommends more research investments in understanding the differentiated outcomes of these forms of social capital on use and adoption of technologies to further guide agricultural interventions.
\end{abstract}

Key Words: gender; smallholder farmers; social capital; soil management

\section{INTRODUCTION}

In rural areas of sub-Saharan Africa (SSA), most people depend on agricultural production for their livelihoods. In the last three decades, numerous advances have been made in agricultural research and technology generation for increasing agricultural productivity in SSA, and for ensuring sustainable use of scarce natural resources. Adoption of such technologies has the potential to increase yields and reduce poverty, as seen in South Asia and East Asia where per capita gross domestic product (GDP) rose annually by $2.3 \%$ and $3.1 \%$, respectively, over the last three decades (World Bank 1996). An integral part of sustained poverty reduction efforts is improved soil management and sustainable use of natural resources (KabuboMariara et al. 2007, Nkonya et al. 2004). Andriesse et al. (2007), in an analysis of reports by bilateral and multilateral donors and development agencies on the role of agriculture in stimulating pro-poor economic growth and reducing hunger, found that most reports recognize the need for priority investments in the restoration of soil fertility and sustainable use of natural resources. Investments in soil management options, however, need to be accompanied by farmer capacity and willingness to use soil fertility and natural resource management options to improve agricultural productivity. At the farmer level, although there are many factors that influence adoption and use of these technologies, studies have shown that rural communities that are characterized by strong social capital have faster rates of technology diffusion and improved environmental management (Claridge 2007, Woolcock and Sweetser 2007). This is because social capital may be the most important resource available for poor communities that are often burdened with low incomes, poor education, and few material and financial assets (Woolcock and Sweetser 2007). Social capital, however, influences the use of technologies differently; for example, technologies that are knowledge intensive may require different forms of social capital than those that are labor or input intensive. Studies on the links between social capital and agricultural technologies

\footnotetext{
${ }^{1}$ International Centre for Tropical Agriculture (CIAT), ${ }^{2}$ Department of Agricultural Economics, University of Pretoria, ${ }^{3}$ Tropical Soil Biology and Fertility Institute of CIAT
} 
have, however, not differentiated the different forms of social capital and how these influence the adoption and utilization of different technologies.

\section{TYPES AND MEASUREMENT OF SOCIAL CAPITAL}

The term "social capital" has become increasingly popular in different disciplines and an important variable in contributing to rural development. As a result of its popularity and wide application, it has generated different definitions, classifications, and measurement methods (see Bourdieu 1986, Coleman 1988, 1990, Putnam 1993). It is often quoted that social capital is "features of social organization such as networks, high levels of interpersonal trust and norms of mutual aid and reciprocity which act as resources for individuals and facilitate collective action" (Putman 1993, Lochner et al. 1999). Bourdieu (1986) defines it as the "aggregate of the actual or potential resources which are linked to possession of a durable network of more or less institutionalized relationships of mutual acquaintance and recognition-or in other words to membership in a group-which provides each of its members with the backing of the collectively owned capital." Lochner et al. (1999) adds that social capital has a collective dimension as it is external to the individual and the structure of social capital is hence different from economic capital (money, financial capital) or human capital, e.g., education and training, which are more individual. Benefits of social capital can, however, accrue to the individual as Portes (1998) argues in the definition that social capital is the ability of individuals to secure benefits through membership in networks and other social structures. Social capital captures network-based processes or aspects of social structure that generate communal benefits through norms and trust (Office for National Statistics 2001, Durlauf and Fufchamps 2004). It is the establishment of norms that permit people to work in groups, hence social capital is the consequence of intensely rooted cultural habits (Fukuyama 2004), and as a result, it is defined differently in different cultural settings. The vast literature on social capital further refines its definition to distinguish between bonding, bridging, and linking social capital.

\section{Bonding Social Capital}

Bonding social capital is generally defined as closed networks of close friends and relatives or horizontal relationships among equals within a localized community (Claridge 2007, Beugelsdiyk and Smulders 2003). It is the social cohesion that takes place between individuals of similar ethnic backgrounds or social status and it is reinforced by working together (Sanginga et al. 2007a). Szreter and Woolcock (2004) define bonding social capital as the trusting and cooperative relations between members who are similar in a sociodemographic sense. Some examples of this type of social capital include formal and informal clubs, groups, or associations established by farming communities in many villages across SSA. These groups may be formed through church affiliations, local traditional structures, or other localized structures. Bonding social capital is thus characterized by trust and norms that exist within the social structure. Bridging social capital, on the other hand, is widely agreed to be vertical relationships or networks that cross social groupings. These are established between people or organizations that are removed from each other and are in different communities (Claridge 2007, Beugelsdiyk and Smulders 2003).

\section{Bridging Social Capital}

Bridging social capital links networks requiring collaboration and coordination with other external groups to achieve set goals; for example, it can be the link between two local groups from different villages. Leonard and Onyx (2003) use five indicators of social capital (networks, reciprocity, trust, shared norms, and social agency) developed by Onyx and Mullen (2000) to define bonding and bridging social capital. The authors define bonding social capital as characterized by dense, multiplex networks, long-term reciprocity, thick trust, shared norms, and less instrumentality, whereas bridging social capital is characterized by large, loose networks, relatively strict reciprocity, and a thinner or different type of trust and more instrumentality.

\section{Linking Social Capital}

Linking social capital is the engagement of local groups or networks with institutions or agencies in higher influential positions (Office for National Statistics 2001, Sanginga et al. 2004, Woolcock and 
Sweetser 2007). Through linking social capital, groups of poor people are able to access support, resources, and information from organizations and networks. Szreter and Woolcock (2004) define it as the "norms of respect and networks of trusting relationships between people who are interacting across explicit, formal, or institutionalized power or authority gradients in society," such as citizens' interactions with local government.

Woolcok and Narayan (2000) see bonding social capital as operating as a defense mechanism against poverty, whereas bridging social capital is what is required for real economic growth to take place. They see bonding social capital as what communities use to "get by" and bridging social capital as what they use to "get ahead." Leonard and Onyx (2003), however, argue that bridging social capital should not replace bonding social capital as communities have multiple sources of social capital that they draw on for different functions. The three types of social capital, therefore, complement each other, in that the strong bonds existing in bonding social capital are diversified by the existence of bridging social capital, whose bonds are weaker but more cross cutting, hence enabling increased diversity in an otherwise closed community. Linking social capital allows for the accumulation of resources, information, and wealth, which is needed by networks to achieve set objectives. Hence, all three types of social capital can coexist in a community to different extents, but more frequently one maybe more prominent.

With these differences between the three types of social capital, it can be assumed that they have differentiated outcomes, some of which are quantitative in nature. Farmer groups, such as farmer associations or cooperatives, create social relations and enable individuals to achieve goals that they are not able to achieve by themselves. For example, farmers can benefit from economies of scale when sharing transport to access inputs or rely on help in case of sickness or need due to the extended number of friends or people they can trust. More so, frequent interaction will most likely increase the access to information as close friends are likely to share knowledge and information. The functioning of marketing groups is based on the "ability of the group to cooperate on the trust between members" (Lyon 2000). Farmer groups have also been known to enhance the productivity of agri-businesses and are used as a channel for delivering services (Chamala and Shingi 1997). Membership into farmer groups further enables individuals to have access to capacity building efforts such as training and study tours, and to information pertaining to new agricultural technologies. The farmer group or other local-level community formal or informal structures shape norms, such as extent of trust, abiding by bylaws, settling conflicts, cooperation among members, giving gifts, or exchanging items, as well as the extent of financial contributions toward group activities or collective community problems.

Numerous studies have shown that social capital facilitates the diffusion of innovations by increasing the inter-linkages among individuals (Hobbs 2001). And many more studies have been conducted to demonstrate the role of social capital in adoption of various technologies (Chou 2002, Skinner and Staiger 2005, Huijboom 2007). More recently, a number of studies have specifically looked at the role of social capital in the adoption of improved agricultural technologies, such as the adoption of improved inputs, soil and water conservation technologies, agro-forestry technologies, and improved crop management (Parthasarathy and Chopde 2000, Isham 2002, Sanginga et al. 2004, $2007 \mathrm{a}, \mathrm{b})$. All these studies concur that social capital has a positive impact on the adoption and use of improved agricultural technologies. Most of these studies linking social capital to technology use and adoption have mainly used qualitative measures of social capital, such as membership in groups or associations. Few studies have attempted to isolate the different types and aspects of social capital from a quantitative perspective.

This paper looks at the empirical measurement of social capital, uses this to differentiate the different forms of social capital, and analyzes how these different forms influence the adoption and use of soil management technologies. The paper uses factor analysis to group social capital variables into three categories, thus providing an empirical analysis of the links between different types of social capital and technology use. This paper postulates that different types of social capital facilitate - to different extents - networking among rural households, which results in accumulation of knowledge and in adoption of improved soil management options. The paper contributes to the current debates in social capital by providing an empirical, quantitative method for the measurement of the different forms of social capital and the relationships that these have with the use of improved technologies by smallholder farmers. 


\section{METHODOLOGY}

\section{Study Location and Sampling}

The study was carried out in the Chinyanja Triangle, which is composed of the Eastern Province of Zambia, Southern and Central Regions of Malawi, and Tete Province of Mozambique, where the predominant language is Chinyanja. In this area, agriculture is the most predominant source of livelihood (Myburgh and Brown 2006). The area is not easily accessible and agricultural inputs are transported over long distances, making them costly and unaffordable for most smallholder farmers. Population is very dense and the land-holding size for most households is less than 1 ha (Ajayi et al. 2003, Myburgh et al. 2006).

A four-stage cluster sampling technique was used to select a total of 630 farming households from Malawi, Zambia, and Mozambique. In the first stage of clustering, the three countries were purposefully selected from Southern Africa based on the criteria that they share geographical boundaries and the Nyanja language and form the Chinyanja Triangle area. In the second stage of sampling, five sites were purposefully selected from each of five districts across the three countries. Two districts were selected from Malawi (Lilongwe and Kasungu), two from Mozambique (Tsangano and Angonia), and one from Zambia (Chipata District). The districts were selected purposefully based on the criteria that several research and extension institutions are working in those districts to promote soil fertility management technologies, including the appropriate use of organic and inorganic fertilizers. In the third stage of sampling, eight communities or villages were purposefully selected to target areas working within a USAID-funded Livelihoods Improvement Program within the Chinyanja Triangle. The fourth stage involved random selection of 630 households from within the group villages.

A semi-structured questionnaire was used to collect information on key variables of social and human capital, knowledge and use of improved soil management options, information pertaining to crop and livestock production, income-generating activities, markets and agro-enterprises, food security and dietary diversification, fertilizer use, as well as gender relations. For social capital variables, respondents were asked a set of questions relating to households relationships with others in and outside their communities.

\section{Data Analysis}

Factor analysis is used in this paper to identify the concealed types of social capital that exist and that are manifested in features of social organizations. The different types of social capital are both observable and unobservable variables as they result from complex social interactions, such as trust, norms, and shared values, whose tangibility can be measured through individual member perceptions (Durlauf and Fufchamps 2004). Factor analysis can concurrently manage large sets of variables with unknown interdependencies by using correlations to group sets of variables (Rummel 2007), where each group represents a single hidden factor. The social capital variables in this study were analyzed using the Principal Axis Factoring Method with Varimax rotation. By default, only factors with eigenvalues greater than one are retained in the analysis; for this study, however, only factors whose eigenvalues were greater than 1.3 were retained, as this entails that the factor is accounting for a greater proportion of the variance than the original variable and hence it facilitates better interpretation. Additionally, only variables with factor loadings greater than 0.3 were used for the factor analysis. Using factor score regression, a new data set representing each household sampled was generated and this was used to incorporate social capital as a variable in the development of a logit model to analyze the relationship between the social capital factors existing and the use of improved agricultural technologies. Onyx and Mullen (2000) have similarly used factor analysis to group social capital variables.

Choices between different strategies are commonly modeled using binary models like probit and logit. Logit regression was used to analyze the determinants of farmers' use of certain technologies. Several studies have used the logit model in relation to adoption of different technologies (Mariam et al. 1993, Buckles et al. 1998, Zegeye et al. 2001, De Groote et al. 2002, Cramb 2004, Nyende and Delve 2004). The estimated regression model predicts the probability that the dependent variable takes a value of 1 .

$\operatorname{Logit}\left(p_{i}\right)=\ln \left(p_{i} / 1-p_{i}\right)=\beta_{1} x_{1, i}+\ldots .+\beta_{k} x_{k, i}$

The unknown parameters $\beta_{\mathrm{j}}$ are usually estimated by likelihood. The interpretation of the $\beta_{j}$ parameter estimates is as the additive effect on the log odds ratio for a unit change in the $j$ th explanatory variable. 
The three social capital variables extracted in the factor analysis are included as variables in the logit model using the factor scores that were generated.

\section{RESULTS AND DISCUSSION}

\section{Principal Factor Analysis}

From the analysis of social capital variables used in the Factor Analysis, three underlying factors of social capital emerged (Table 1). Factor 1 can be termed "Bonding Social Capital." This is because different variables that facilitate creation of cohesion among people in a community have high positive loadings. This includes cooperation among people (0.848), extent of trust among people $(0.784)$, and participation in community activities (0.654). Other signs of solidarity, such as the extent of settling conflicts and extent of abiding by norms, also have factor loadings that can be considered to be on the greater side (greater than 0.3). The extremely high positive loading on cooperation, implies that creation of trust, settling of conflicts, participation in community activities, and abiding by norms are all enabled by an environment where there is high cooperation between and among the people. These findings concur with studies by Bowles and Gintis (2002, as quoted by Durlauf and Fufchamps 2004) that found that bonding social capital generally refers to trust and a willingness to live by norms and bylaws of one's community.

Bonding social capital as seen from the factor loadings is a characteristic of within-group relations, the extent to which people within the same group or community cooperate with each other, participate in joint activities, and the extent to which they trust one another. Pretty et al. (2005) defines bonding social capital as the connectedness that exists between individuals within local groups and communities or what they refer to as local connections. It is the links between people that have similar outlooks and objectives. These connections may take many forms, such as exchange of information, exchange of gifts and reciprocity, helping each other out, working collectively toward a common goal among other things. Bonding social capital is linked to high levels of trust, reciprocity, and community action. These characteristics of bonding social capital are expected to be positively linked to adoption and use of technologies that require collective action, such as soil erosion control, pest and disease management, and management. The bonding social capital is also expected to have a positive relationship with technologies that require pooling of labor due to their labor-intensive nature. Some groups in Kenya, for example, were formed for the purpose of pooling and sharing labor across households especially for soil and water conservation.

The second factor of social capital that has emerged with high positive loadings can be associated with bridging and linking social capital. Variables loading onto this factor include membership in groups outside of one's community, extent of financial contributions for group and wider collective activities, and links with extension staff and access to training by other organizations. All these variables have aspects of links or networking across groups and with outside organizations. The bridging and linking social capital implies links across groups, across communities, and with other organizations. These two types of social capital are expected to have a positive relationship with knowledge-intensive technologies that require sharing of information on their use, training, or visiting other farmers, research institutions, and other organizations where these technologies are developed or demonstrated. It is not surprising that group formation and the presence of extension have loaded highly on the same factor as empirical evidence has shown that one of the key roles of extension service providers is to help farmers or community members empower themselves to form groups that are organized for development.

The third factor that does not seem to fit within any of the existing social capital classifications in the literature is related to gender relations at the community level, as indicated by high positive loadings on women's ability to speak with confidence in pubic and men's respect and consideration of ideas given by women. These two factors represent women's empowerment and improved gender relations at the community level, and this could be enhanced due to the high levels of cohesion that exist within the communities as explained by factor 1 . The higher loading on men's respect and consideration for women's ideas indicates empowerment of women and men's acceptance of women as partners in development. We have called this factor "gendered social capital" and it is expected to have a positive relationship with technologies that favor women, whether in terms of reducing their labor or increasing their cash returns. 
Table 1. Principal factor analysis of social capital variables

\begin{tabular}{llcc}
\hline \hline Social Capital Variables & \multicolumn{2}{c}{ Underlying factors (Unobservable) } \\
& $\begin{array}{l}\text { Factor 1: } \\
\text { Bonding }\end{array}$ & $\begin{array}{c}\text { Factor 2: } \\
\text { Gender }\end{array}$ & $\begin{array}{c}\text { Factor 3: Bridging } \\
\text { and Linking }\end{array}$ \\
\hline Training or participation in study tours & - & - & -0.334 \\
Membership in a farmer group & - & - & 0.690 \\
Membership in more than one farmer group & - & - & 0.462 \\
Participation in community activities & 0.654 & - & - \\
Extent of trust among people & 0.784 & - & - \\
Cooperation among people & 0.848 & - & - \\
Extent of giving or exchanging gifts & - & - & - \\
Extent of financial contribution for community activities & - & - & - \\
Extent of financial contributions for farmer group activities & - & - & - \\
Spirit of helping others, especially the poor & - & - & - \\
Extent of settling of conflicts & 0.434 & 0.399 & - \\
Extent of abiding by the norms and bylaws & 0.397 & 0.475 & - \\
Women having confidence to speak in public & & 0.670 & - \\
Men's respect for and consideration of ideas given by women & - & 0.787 & - \\
Presence of extension worker in community & - & - \\
\hline
\end{tabular}

Kaiser-Meyer-Olkin (KMO) measure $=0.753$

${ }^{[1]}$ These are features of social organization that are observable.

\section{Technology Use}

Several soil management options were considered. The technologies, their characteristics, and uses are summarized in Table 2.

From Table 3 it can be seen that different types of technologies are widely used in different combinations across the three countries. Two of the most commonly used technologies in Malawi besides inorganic fertilizer were early ploughing (49\%) and incorporation of crop residues $(47 \%)$. In Zambia, the most commonly used technologies were crop rotation $(86 \%)$ and the use of animal manure $(47 \%)$. Incorporation of crop residue was used by $85 \%$ of the farmers in Mozambique, whereas early ploughing was used by $47 \%$. Across the three countries, crop rotation was the most commonly used technology, with $57 \%$ of farmers using it, followed by incorporation of crop residue and early ploughing. The use of botanicals was not common, and was used by less than 10 of the 630 farmers interviewed. 
Table 2. Soil management options, their characteristics and uses

\begin{tabular}{|c|c|}
\hline Soil management options & Short description \\
\hline Crop Rotation & $\begin{array}{l}\text { Production system where different crops are grown in sequence to avoid } \\
\text { continuous cultivation of the same crop, on the same land, year after year }\end{array}$ \\
\hline Incorporation of crop residue & $\begin{array}{l}\text { Process of adding crop residues to the soil, either through ploughing in, or by } \\
\text { mulching and allowing macro-fauna to incorporate residues with time }\end{array}$ \\
\hline Animal manure & $\begin{array}{l}\text { Collection, management, and use of animal manure for increasing nutrient and } \\
\text { organic matter additions to the soil }\end{array}$ \\
\hline Agroforestry trees & Planting of tree species either as a rotation, a fallow, or on field/farm boundaries \\
\hline Resting land fallow & $\begin{array}{l}\text { Removal of land from crop production for a number of seasons to allow the soil } \\
\text { fertility to replenish }\end{array}$ \\
\hline Soil erosion control & $\begin{array}{l}\text { Process of active control of water movement across the soil surface, either by } \\
\text { terracing, using trash lines, or fanya juu, fanya chini }\end{array}$ \\
\hline Early ploughing & $\begin{array}{l}\text { Early land preparation to allow more timely seed sowing and for improved weed } \\
\text { control }\end{array}$ \\
\hline Cover crops & $\begin{array}{l}\text { Use of certain species, mostly nitrogen fixing, as a sole or relay crop, to provide } \\
\text { ground cover during the dry season, provide biomass of soil fertility } \\
\text { improvement, conserve soil moisture, and provide dry season livestock feed }\end{array}$ \\
\hline $\begin{array}{l}\text { Botanicals for pest and disease } \\
\text { management }\end{array}$ & $\begin{array}{l}\text { Use of local species like Tithonia, chili, marigold to prepare a water-based } \\
\text { pesticide }\end{array}$ \\
\hline
\end{tabular}

\section{Relationship between Social Capital and Technology Use}

Adam and Roncevic (2003) make several conceptualizations of social capital, one of which is social capital as catalyst for disseminating human and intellectual capital. They postulate that economic capital on its own is not sufficient to achieve certain development goals and that social capital is required as an asset that can facilitate the circulation, recombination, and reconfiguration of human capital in order to make it useful for technological application and for the solution of both social and economic problems. The authors see a slow link between social capital and the application of human and technological knowledge.

The factors influencing use of the technologies varied widely and these are presented in the results of the logit model (Table 4). Bridging and linking social capital significantly influenced the use of crop rotation, crop residues, planting of agroforestry trees and the use of inorganic fertilizers. Gender was more linked to soil erosion structures, planting of agroforestry trees, use of cover crops, and fallows. Crop residue incorporation increases the organic matter content of soil and hence soil fertility. The type of residue, time of incorporation, and role in organic matter in crop production is a knowledgeintensive process, and this knowledge is acquired through technology messages, on-farm demonstrations, and field visits to other farmers using these technologies. This is unlike other less knowledgeintensive technologies, e.g., inorganic fertilizers. Results show that farmers with more linking and bridging social capital use these technologies more than farmers who have fewer links (Table 4). Kiptot et al. (2006) found that although informal and kinship networks were useful for the dissemination of seed, they were not commonly used for dissemination of knowledge and knowledgeintensive technologies.

Although social capital increases farmer's adoption of soil conservation measures (Cramb 2004), the results show that it has a significant negative 
Table 3. Use of soil management technologies across the Chinyanja Triangle

\begin{tabular}{lccccc}
\hline \hline & \multicolumn{2}{c}{ Percentage of farmers using technology } & & \\
Technology & Malawi & Zambia & Mozambique & Total & \\
& & & & & Chi-square value \\
\hline Crop rotation & 52.1 & 85.9 & 39.4 & 56.6 & $66.674^{* * *}$ \\
Incorporation of crop residue & 46.5 & 34.1 & 85.4 & 52.3 & $82.972^{* * *}$ \\
Animal manure & 27.7 & 47.4 & 43.8 & 35.5 & $21.900^{* * *}$ \\
Agroforestry trees & 20.2 & 26.7 & 26.3 & 22.9 & 3.48 \\
Resting land fallow & 16.8 & 31.9 & 18.2 & 20.3 & $14.157^{* * *}$ \\
Farmyard manure & 38.2 & 18.5 & 20.4 & 30.1 & $25.795^{* * *}$ \\
Soil erosion control & 27.2 & 26.7 & 39.0 & 29.7 & $7.223^{* *}$ \\
Early ploughing & 49.0 & 24.4 & 47.4 & 43.4 & 25.249 \\
$\quad$ Cover crops & 16.9 & 3.7 & 13.2 & 13.3 & $14.813^{* * *}$ \\
Botanicals for pest and disease & 1.7 & 0.0 & 0.0 & 1.0 & $4.615^{* * *}$ \\
\hline management & & & & \\
\hline
\end{tabular}

relationship with crop rotation, planting of agroforestry trees, and use of inorganic fertilizers (Table 4). One reason is that it is smallholders with larger land sizes and access to capital that most often use crop rotations and purchase inorganic fertilizers and these smallholders are the least likely to depend on social networks for support compared with poorer households with smaller land holdings. A Pearson test showed a negative significant correlation (at $p=0.01$ ) between the bonding and linking social capital and land size indicating the greater the land size, the lower the farmers' bonding and social capital.

Bonding social capital was found to be positively significant in influencing the use of cover crops. This implies that stronger bonds or cohesion within a community will lead to more members growing cover crops. This can be attributed to that for many rural communities with low access to improved technologies; access to seeds for many crops, including cover crops, is through informal networks and interactions (Winters et al. 2006) and within a village of clansmen, the seeds are shared and this positively influences their use. A study in Kenya (Kiptot et al. 2006) found that most seed dissemination of agroforestry trees and shrubs were along kinship ties rather than formal systems of seed distribution. It is, however, not surprising that the existence of bonding social capital was only significant in influencing the adoption of one type of improved technology. Other studies conducted by Winters et al. (2006) similarly found that households with strong bonding social capital are less likely to be diversified in their adoption and use of improved innovations.

Gender was expected to have a positive relationship with technologies that were in favor of women, either in terms of increasing their incomes, improving their access to resources or reducing their labor. This category of technologies included agroforestry trees and legume cover crops. In this analysis, gender social capital was found to have a positive and significant relationship with agroforestry trees, which may be attributed to the fact that the use of agroforestry trees increases access by women to firewood sources, fodder for 
Table 4. Factors influencing use of different soil management technologies in the Chinyanja Triangle

\begin{tabular}{|c|c|c|c|}
\hline Variable & Coefficient & Std. error & $p$ value \\
\hline \multicolumn{4}{|l|}{ Soil Erosion structures } \\
\hline Constant & -1.561 & 0.518 & $0.003 * *$ \\
\hline Sex of household head & 0.761 & 0.281 & $0.007 * *$ \\
\hline Perception of poverty & -0.114 & 0.232 & 0.625 \\
\hline Perception of fertilizers & -0.393 & 0.208 & $0.059 *$ \\
\hline Perception of soil fertility & -0.497 & 0.160 & $0.002 * *$ \\
\hline Hiring of labor & -0.078 & 0.222 & 0.722 \\
\hline Land area in ha & 0.356 & 0.083 & $0.000 * * *$ \\
\hline Bonding & -0.289 & 0.113 & 0.798 \\
\hline Bridging and linking & 0.0139 & 0.126 & 0.913 \\
\hline Gender & 0.254 & 0.122 & $0.038 *$ \\
\hline Age of household head & 0.007 & 0.006 & 0.260 \\
\hline Household income & 0.004 & 0.003 & 0.109 \\
\hline \multicolumn{4}{|l|}{ Crop rotation } \\
\hline Constant & -0.037 & 0.488 & 0.939 \\
\hline Sex of household head & -0.049 & 0.244 & 0.984 \\
\hline Perception of poverty & 0.058 & 0.225 & 0.794 \\
\hline Perception of fertilizers & -0.516 & 0.209 & $0.014 *$ \\
\hline Perception of soil fertility & -0.155 & 0.149 & 0.299 \\
\hline Hiring of labor & 0.638 & 0.219 & $0.004 * *$ \\
\hline Land area in ha & 0.616 & 0.116 & $0.000 * * *$ \\
\hline Bonding & -0.173 & 0.109 & 0.113 \\
\hline Bridging and linking & -0.366 & 0.123 & $0.003 * *$ \\
\hline Gender & -0.627 & 0.111 & 0.575 \\
\hline Age of household head & 0.006 & 0.006 & 0.302 \\
\hline Household income & -0.001 & 0.002 & 0.580 \\
\hline
\end{tabular}


Constant

Sex of household head

Perception of poverty

Perception of fertilizers

Perception of soil fertility

Hiring of labor

Land area in ha

Bonding

Bridging and linking

Gender

Age of household head

Household income

Agroforestry trees

Constant

Sex of household head

Perception of poverty

Perception of fertilizers

Perception of soil fertility

Hiring of labor

Land area in ha

Bonding

Bridging and linking

Gender

Age of household head

Household income

Cover crops

Constant

Sex of household head

Perception of poverty
$-1.281$

0.271

$-0.011$

$-0.102$

0.903

$-0.377$

0.076

0.072

0.261

0.025

$-0.002$

0.001

$-1.704$

$-0.182$

$-0.164$

$-0.679$

$-0.007$

0.340

0.091

$-0.090$

$-0.562$

0.308

0.014

0.002

$-0.830$

0.554

0.602
0.469

0.231

0.218

0.197

0.141

0.207

0.061

0.102

0.120

0.106

0.006

0.003

$0.006 * *$

0.241

0.960

0.604

0.524

$0.069 *$

0.211

0.482

$0.030 *$

0.811

0.726

$0.004 * *$

0.269

$0.002 * *$

0.499

0.501

$0.002 * *$

0.217

0.962

0.135

0.169

0.447

0.118

$0.000 * * *$

0.140

0.136

$0.024 *$

0.007

$0.047 *$

0.002

0.368 
Perception of fertilizers

Perception of soil fertility

Hiring of labor

Land area in ha

Bonding

Bridging and linking

Gender

Age of household head

Household income

Fallows

Constant

Sex of household head

Perception of poverty

Perception of fertilizers

Perception of soil fertility

Hiring of labor

Land area in ha

Bonding

Bridging and linking

Gender

Age of household head

Household income

Inorganic Fertilizer

Constant

Sex of household head

Perception of poverty

Perception of fertilizers

Perception of soil fertility

Hiring of labor
$-1.018$

$-0.460$

0.227

0.104

0.787

$-0.168$

0.680

$-0.006$

$-0.003$

$-2.793$

0.808

$-0.660$

$-0.999$

$-0.173$

0.251

0.296

$-0.151$

$-0.079$

$-0.270$

0.023

0.001

2.596

$-0.694$

0.447

$-0.348$

$-0.076$

0.938
0.276

0.220

0.298

0.072

0.224

0.171

0.209

0.009

0.005

0.618

0.326

0.281

0.233

0.182

0.246

0.085

0.124

0.149

0.129

0.007

0.002

0.566

0.287

0.275

0.239

0.166

0.267
$0.000 * * *$

$0.036^{*}$

0.446

0.150

$0.000 * * *$

0.324

$0.001 * *$

0.539

0.557

$0.000 * * *$

0.013*

$0.019^{*}$

$0.000 * * *$

0.339

0.307

$0.001 * *$

0.222

0.593

0.037 *

$0.003 * *$

0.550

$0.000 * * *$

$0.016^{*}$

0.104

0.147

0.649

$0.000 * * *$ 


\begin{tabular}{lccc}
\hline Land area in ha & 0.191 & 0.114 & $0.094^{*}$ \\
Bonding & 0.135 & 0.118 & 0.253 \\
Bridging and linking & -0.444 & 0.144 & $0.002^{* *}$ \\
Gender & -0.112 & 0.126 & 0.374 \\
Age of household head & -0.004 & 0.007 & 0.543 \\
Household income & 0.001 & 0.006 & $0.039^{*}$ \\
\hline
\end{tabular}

livestock, and fruit trees. Although the study did not distinguish what kind of agroforestry trees were being planted by households, it can be assumed that some of these trees have uses of benefit to women. Cover crops as expected were also found to have a significant relationship with the gender variable. Cover crops are mainly legumes, such as soyabeans, lablab, and groundnuts. For women, legumes offer a more attractive source of household income than traditional cash crops in southern Africa, such as tobacco, cotton, and maize as these are often controlled by men. The positive significant relationship between soil erosion control and gender was unexpected. It had been hypothesized that due to the high labor requirement of constructing and maintaining soil erosion control structures, that the relationship between the gender variable and soil erosion structures would be negative. However, one of the most common form's of soil erosion control in Malawi is the planting of vetiver grass. Apart from being an effective mechanism for the control of erosion, the grass also provides fodder within the confines of their own farms for livestock, thereby reducing women's time and labor for harvesting fodder in communal areas. Additionally, the positive relationship also means that, as women are empowered, they are better able to find means of ensuring that labor-intensive technologies that normally elude them, are incorporated into their farmsteads. The negative significant relationship between gendered social capital and fallowing of land is not unexpected. Literature shows that land owned and managed by women is often under utilized due to lack of sufficient labor, information, education, and resources (Food and Agriculture Organization (FAO) 1995, Pinkard 2006).

\section{Other Determinants of Technology Use}

From the analysis, the sex of the household head was found to have a positive and significant relationship with soil erosion control and fallows, and a negative relationship with inorganic fertilizers. This implies that households that were headed by men were more likely to use soil erosion structures and fallows than households headed by women. The effects of the sex of the head of household, however, has more to do with the unequal access to resources by women, which is common in most African countries. Women have been found to have less access and control of resources, such as land and property, and less access to services such as agricultural credit and information (Quisumbing et al. 1995, Njuki 2001).

Various studies have looked at the role of land size in determining the use of soil and water management technologies (Isham 2002, Kaliba et al. 2000, Marenya and Barrett 2007, Waithaka et al. 2007). The probability of using fertilizer, fallows, crop rotation, and soil erosion control was positive and significant. Although some of the technologies, such as fallows, are land and scale dependent and not appropriate for households with small land sizes, for others the effects may be due to other factors that are related to land. These may include the fact that wealthier households have bigger farm sizes and are also able to purchase fertilizers, and they have a broader crop mix and therefore use crop rotations. A study by Marenya and Barrett (2007) found significant relationships between farm size and the use of stover lines, agroforestry, manure, and inorganic fertilizers in Western Kenya. Older heads of households were more likely to use agroforestry trees and fallows. This is due to the larger land sizes associated with older people. In the customary land-tenure system common in the three 
countries, land is distributed by traditional chiefs. Young people, when they marry, then receive land from the chief or from their parents. Due to this agedependent system, younger people tend to have smaller land sizes than older people.

One of the commonly neglected factors in assessing the use of technologies by smallholder farmers is the role of farmers' own perceptions of both the technologies and the status of their soils. Farmers' perceptions were found to play an important role in determining the use of technologies. Farmers who perceived fertilizers to be bad for the soil were more likely to use other soil management options. There was a negative correlation between the perception of fertilizers as good for the soil and the use of most of the technologies, including crop rotation, agroforestry trees, cover crops, and fallows. Farmers who perceived their soils to be fertile were also less likely to use soil management options and soil erosion control strategies. This was especially significant for the use of cover crops, and soil erosion management. Although farmers' perceptions of different technologies have been sought, studied, and documented, they have rarely been used ito model the determinants of technology use.

\section{CONCLUSIONS AND RECOMMENDATIONS}

The results of this study show that the use of various soil management technologies depends on socioeconomic variables and the existence of different dimensions of social capital. Social capital is especially important in determining whether households have access to, and therefore use, different soil management technologies. Although different studies have looked at social capital in terms of membership in groups, this study shows the need to differentiate different kinds of social capital as these influence technology adoption differently. There is, therefore, a need to develop multiple indicators for measuring the different forms of social capital and how these forms influence research and development outcomes. The study finds that bonding, bridging, and linking social capital all influence the adoption and use of different soil fertility management options, a trend that might be similar for other agricultural technologies as well. The study recommends investments especially by development organizations in strengthening these different forms of social capital by supporting local kinship or community groups that generate social capital, promoting farmer access and links with external organizations that can act as sources of information and technologies for farmers, as well as links with other farmer associations and groupings from whom they can learn.

Gendered social capital was found to be a critical factor in improving the adoption and use of technologies that are especially beneficial for livelihood outcomes. Extension and community development programs, therefore, need to deliberately incorporate gender within extension and other programs aimed at increasing access to technologies; they need to promote technologies that are beneficial to women in terms of increasing their incomes or reducing their labor. Efforts to promote the empowerment of women, increase their voice, and improve household gender relations are crucial. Lastly, in order to broaden the knowledge base and adoption of improved technologies, it is essential that the entry point for working with communities ensures that there are links between these communities and other groups of farmers in order to broaden the scope for networking beyond local community and kinship groupings.

Responses to this article can be read online at:

http://www.ecologyandsociety.org/voll3/iss2/art9/responses/

\section{Acknowledgments:}

This study is part of the Livelihoods Improvement Programme in the Chinyanja Triangle. We would like to acknowledge USAID for the financial support. We would like to thank the Citizen Network for Foreign Affairs (CNFA), Total Land Care (TLC) in Malawi, Mozambique, and Zambia and the Department of Agricultural Research, Zambia for their support with the data collection.

\section{LITERATURE CITED}

Adam, F., and B. Roncevic. 2003. Social capital: recent debates and research trends. Social Science Information 42(2): 155-183.

Ajayi, O. C., S. Franzel, E. Kuntashula, and F. Kwesiga. 2003. Adoption and profitability of agro forestry-based soil fertility management technologies. International Research on Food Security, Natural 
Resource Management, and Rural Development. Georg-August-Universität: Göttingen, Germany.

Andriesse, W., K. Giller, J. Jiggins, H. Loffler, P. Oosterveer, and J. Woodhill. 2007. The role of agriculture in achieving $M D G$ 1: a review of leading reports. Wageningen International, Wageningen, The Netherlands.

Beugelsdiyk, S., and S. Smulders. 2003. Bridging and bonding social capital: which is good for economic growth. Forty-third European Regional Science Association Congress, 27-30 August 2003, Jyväskylä, Finland. [online] URL: http://www.ersa. org/ersaconfs/ersa03/cdrom/abstracts/a517.html.

Bourdieu, p. 1986. The forms of capital. Pages 241-258 in J. G. Richardson, editor. Handbook of theory and research for the sociology of education. Greenwood Press, New York, New York, USA.

Bowles, S., and H. Gintis. 2002. Social capital and community governance. The Economic Journal 112 ( I):419-436.

Buckles, D., B. Triomphe, and G. Sain. 1998. Cover crops in hillside agriculture, farmer innovation with mucuna. International Development Research Centre-International Maize and Wheat Improvement Centre (IDRC-CIMMYT), Ottawa, Ontario, Canada. [online] URL: http://www.idrc.ca/ en/ev-9307-201-1-DO TOPIC.html.

Chamala, S., and P. M. Shingi. 1997. Establishing and strengthening farmer organizations. Pages ??? in B. Swanson, editor. Improving agricultural extension: a reference manual. Food and Agriculture Organization (FAO), Rome, Italy.

Claridge, T. 2007. Social capital. [online] URL: www.gnudung.com.

Chou, Y. K. 2002. Modeling social capital and growth. Research Paper No. 865. University of Melbourne, Department of Economics, Melbourne, Australia.

Coleman, J. S. 1988. Social capital in the creating of human capital. American Journal of Sociology 94:95-120.

Coleman, J. S. 1990. Foundations of social theory. Belknap Press of Harvard University Press, Cambridge, Massachusetts, USA.
Cramb, R.A. 2004. The role of social capital in the promotion of conservation farming: the case of landcare in the South Philippines. School of Natural and Rural Systems Management, The University of Queensland, Queensland, Australia.

De Groote, H., C. Doss, S. D. Lyimo, and W. Mwangi. 2002. Adoption of maize technologies in East Africa: what happened to Africa's emerging maize revolution? Paper presented at the Foundation for Advanced Studies on International Development (FASID) Forum, 8-10 December 2002, Tokyo, Japan.

Durlauf, S., and M. Fufchamps. 2004. Social capital. The University of Wisconsin, Department of Economics, Madison, Wisconsin, USA.

Food and Agriculture Organization (FAO). 1995. Improving the relevance and effectiveness of agricultural extension activities. FAO Corporate Document Repository, Rome, Italy.

Fukuyama, F. 2004. Social capital and development: course overview. John Hopkins University, Baltimore, Maryland, USA.

Hobbs, G. 2001. Social capital formation in Tanzania. Pages ??? in W. S. Samji and A. Albee, editors. Selected studies of civil society in Tanzania: policy, social capital and networks of the vulnerable. UK-Department for International Development (DFID), Dar es Salaam, Tanzania.

Huijboom, N. 2007. Social capital and ICT adoption in the public sector. Pages 140-147 in Association for Computing Machinery (ACM). Proceedings of the 8th Annual International Conference on Digital Government Research: Bridging Disciplines and Domains, 20-23 May 2007, Philadelphia, Pennsylvania, USA. ACM International Conference Proceedings Series, volume 228. Digital Government Society of North America, New York, New York, USA.

Isham, J. 2002. The effect of social capital on fertilizer adoption: evidence from rural Tanzania. Journal of African Economies 11(1):39-60.

Kabubo-Mariara, J., V. Linderhof, G. Kruseman, R. Atieno, and G. Mwabu. 2007. Household welfare, investment in soil and water conservation, and tenure security: evidence from Kenya. Poverty REduction and Environmental Management (PREM) Working Paper No. 06-06. PREM, 
Amsterdam, The Netherlands. [online] URL: http:/ /www.prem-online.org/index.php?p=publications\&a= show\&id=120.

Kaliba, R. M., H. Verkuijl, and W. Mwangi. 2000. Factors affecting adoption of improved maize seeds and use of inorganic fertilizers for maize production in the intermediate and lowland zones of Tanzania. Journal of Agricultural and Applied Economics 32 (1):35-47.

Kiptot, E., S. Franzel, P. Hebinck, and P. Richards. 2006. Sharing seed and knowledge: farmer to farmer dissemination of agroforestry technologies in western Kenya. Agroforestry Systems 68(3):167-179.

Leonard, R., and J. Onyx. 2003. Networking through loose and strong ties: an Australian qualitative study. Voluntas: International Journal of Voluntary and Nonprofit Organizations 14 (2):189-203.

Lochner, K., I. Kawachi, and B. P. Kennedy. 1999. Social capital: a guide to its measurement. Health and Place 5:259-270.

Lyon, F. 2000. Trust, networks and norms: the creation of social capital in agricultural economies in Ghana. World Development 28(4):663-681.

Marenya, P. P., and C. B. Barrett. 2007. Household-level determinants of adoption of improved natural resources management practices among smallholder farmers in western Kenya. Food Policy 32(4):515-536.

Mariam, Y., J. Galaty, and G. Coffin. 1993. Strategic decision making: adoption of agricultural technologies and risk in a peasant economy. Munich Personal RePEc Archive Paper No. 387. LudwigMaximilians-Universität, Munich, Germany. [online] URL: http://mpra.ub.uni-muenchen.de/.

Myburgh, M., and J. Brown. 2006. The potential of information and communication technology as an enabler for agricultural and community development in the Chinyanja Triangle. Agribusiness in Sustainable Natural African Plant Products (ASNAPP), Dennesig, South Africa.

Njuki, J. 2001. Gender roles in agroforestry: a socio-economic analysis of Embu and Kirinyaga Districts, Kenya. Dissertation, Faculty of
Agriculture, Sokoine University of Agriculture, Tanzania.

Nkonya, E., J. Pender, P. Jagger, D. Sserunkuuma, C. Kaizzi, and H. Ssali. 2004. Strategies for land management and poverty reduction. Research Paper Abstract No. 133. International Food Policy Research Institute (IFPRI), Washington, D.C., USA.

Nyende, P., and R. Delve. 2004. Farmer participatory evaluation of legume cover crops and biomass transfer technologies for soil fertility improvement using farmer criteria, preference ranking and logit regression analysis. Experimental Agriculture 40:77-88.

Office for National Statistics. 2001. Social capital: a review of the literature. Social Analysis and Reporting Division, Office for National Statistics, London, UK.

Onyx, J., and P. Mullen. 2000. Measuring social capital in five communities. Journal of Applied Behavioral Science 36(1):23-42.

Parthasaraty, D., and V. K. Chopde. 2000. Building social capital: collective action, adoption of agriculture innovation and poverty reduction in the Indian semi-arid tropics. International Crops Research Institute for the Semi-Arid Tropics (ICRISAT), Andhra Pradesh, India.

Pinkard, O. 2006. Women-managed farms and the open market: female livelihood before and after agricultural trade liberalization in the Middle East and North Africa. Paper presented at the annual meeting of the International Studies Association, 22 March 2006, San Diego, California

Portes, A. 1998 Social capital: its origins and applications in modern sociology. Annual Review of Sociology 21:1-24.

Pretty, J. 2003. Social capital and the collective management of resources. Science 302(5652):1912 1914.

Pretty, J. N., J. Thompson, and J. K. Kiara 1995. Agricultural regeneration in Kenya: the catchment approach to soil and water conservation. Ambio $\mathbf{2 4}$ (1):7-15.

Putman, R. D. 1993. Making democracy work: 
civic traditions in modern Italy. Simon and Schuster, New York, New York, USA.

Quisumbing, A. R., L. Haddad, and C. Pena. 1995. Gender and poverty: new evidence from 10 developing countries. International Food Policy Research Institute, Food Consumption and Nutrition Division (FCND). FCND Discussion Paper No. 9.

Rummel, R. J. 2007. Understanding Factor Analysis. Extracted from R. J. Rummel. 1970. Applied factor analysis. Northwestern University Press, Evanston, Illinois, USA. [online] URL: http: //www.hawaii.edu/powerkills/UFA.HTM.

Sanginga, P., M. Adrienne, and R. Kamugashi. 2004. Strengthening social capital for decision making in natural resource management in the highlands of western Uganda. Paper presented at the $10^{\text {th }}$ Congress of the International Association of Common Property, 9-12 August, 2004, Oaxaca, Mexico.

Sanginga, P., R. Kamugisha, and M. Adrienne. 2007a. Conflict management, social capital, and adoption of agroforestry technologies: empirical findings from the highlands of southwestern Uganda. Agroforestry Systems 69(1):67-76.

2007b. The dynamics of social capital and conflict management in multiple resource regimes: a case of the southwestern highlands of Uganda. Ecology and Society 12(1): 6. [online] URL: http:// www.ecologyandsociety.org/vol12/iss1/art6/.

Skinner, J., and D. Staiger. 2005. Technology adoption from hybrid corn to beta blockers. National Bureau of Economic Research, Cambridge, Massachusetts, USA.

Szreter, S., and M. Woolcock. 2004. Health by association? Social capital, social theory, and the political economy of public health. International Journal of Epidemiology 33:650-67.

Waithaka, M., P. K. Thornton, K. D. Shepherd, and N. N. Ndiwa. 2007. Factors affecting the use of fertilizer and manure by smallholder farmers: the case of Vihiga, western Kenya. Nutrient Cycling Agroecosystems 78(3):211-224.

Winters, P., R. Cavatassi, and L. Lipper. 2007. Sowing the seeds of social relations. The role of social capital in crop diversity. Department of Economics, American University, Washington, D. C., USA.

Woolcock, M., and D. Narayan. 2000. Social capital: implications for development theory, research and policy. World Bank Research Observations 15(2): 225-249.

Woolcock, M., and A. T. Sweetser. 2007. Social capital: the bonds that connect. Asian Development Bank (ADB), Manila, Philippines. [online] URL: www.adb.org

World Bank. 1996. Poverty in Sub-Saharan Africa. Issues and recommendations. Findings: African Region. Vol. 73

Zegeye, T., G. Taye, D. Tanner, H. Verkuijl, A. Agidie, and W. Mwangi. 2001. Adoption of improved bread wheat varieties and inorganic fertilizer by small-scale farmers in Yelmana Densa and Farta Districts of northwestern Ethiopia. Ethiopia Agricultural Research Organization (EARO) and International Maize and Wheat Improvement Center (CIMMYT), Mexico, D.F. 